Vol. 4, No. 1, 2018

\author{
Mykhaylo Student ${ }^{1}$, Galyna Veselivska ${ }^{2}$, Volodymyr Gvozdeckii ${ }^{3}$, Myron Golovchuk ${ }^{4}$, \\ Liudmyla Dzyubyk ${ }^{5}$, Yaryna Sirak ${ }^{6}$ \\ ${ }^{1}$ Department of Superficial Strengthening of Structural Materials, Karpenko Physico-Mechanical institute of the \\ NAS of Ukraine, 5, Naukova Str., Lviv, Ukraine, E-mail: student-m-m@ipm.lviv.ua \\ ${ }^{2}$ Department of Superficial Strengthening of Structural Materials, Karpenko Physico-Mechanical institute of the \\ NAS of Ukraine, 5, Naukova Str., Lviv, Ukraine, E-mail: okhota@ipm.lviv.ua \\ ${ }^{3}$ Department of Superficial Strengthening of Structural Materials, Karpenko Physico-Mechanical institute of the \\ NAS of Ukraine, 5, Naukova Str., Lviv, Ukraine, E-mail: gvosdetcki@gmail.com \\ ${ }^{4}$ Department of Superficial Strengthening of Structural Materials, Karpenko Physico-Mechanical institute of the \\ NAS of Ukraine, 5, Naukova Str., Lviv, Ukraine, E-mail: pminasu@ipm.lviv.ua \\ ${ }^{5}$ Department of Engineering Mechanics and Dynamics of Machines, Lviv Polytechnic National University, \\ 12, S. Bandera Str., Lviv, Ukraine, E-mail: Liudmyla.V.Dziubyk@1pnu.ua \\ ${ }^{6}$ Department of Superficial Strengthening of Structural Materials, Karpenko Physico-Mechanical institute of the \\ NAS of Ukraine, 5, Naukova Str., Lviv, Ukraine, E-mail: pminasu@ipm.lviv.ua
}

\title{
CORROSION-MECHANICAL RESISTANCE OF ARC-SPRAYED COATINGS MADE FROM CORED POWDERS
}

Received: November 14, 2017 / Revised: April 09, 2018 / Accepted: June 26, 2018

(C) Student M., Veselivska G., Gvozdeckii V., Golovchuk M., Dzyubyk L., Sirak Ya., 2018

Abstract. Result of investigations of resistance against corrosion and mechanical resistance of obtained by means of arc-spray metallization (with the use of cored wires) coatings are presented. The cored wires (CWs) enable us to regulate the chemical composition and, consequently, properties of the deposited coating in a wide range. With this, the characteristic feature is its high structural heterogeneity, which is caused by rapidness of the processes of melting of components of the $\mathrm{CW}$ in the arc; this promotes incompleteness of dissolving of change materials in the melt of the metallic shell, and thus, there forms of heterogeneous as to its chemical components melt. The determination of the first-type residual stresses in coatings was conducted according to the developed for bimetal rings technique. The tensile strength (cohesion) of ASC was determined with the use of an experimental set-up which consisted of two pipes.

Electrochemical investigations were conducted in an electrochemical cell in potentiodynamic regime with the use of hard-ware-software complex which was designed for automation of investigations with the help of СВЛ-1Б-М voltamperometric system. The rate of corrosion was determined by means of extrapolation of linear segments of polarization curves to the potential of corrosion or on the basis of segments which corresponded to passive state.

In order to develop experimental sets of CWs, there additionally were investigated some materials with different charge components (chromium, ferro-chromium, boron carbide, ferrochromium-boron, ferro-silicium, ferro-manganise, self-fluxing alloy) (Table 1).

High hardness is characteristic of coatings made from CWs. Such a high hardness is due to $3 \%$ of boron in the coating. However, the cohesive strength of such coating is low and does not exceed $100 \mathrm{MPa}$. This is caused by high tensile residual first-type stresses, which can lead to emergence of crack during machining. In order to reduce the level of residual stresses, it is necessary to preliminarily heat machine parts to $150-2000{ }^{\circ} \mathrm{C}$.

Electrochemical parameters and the character of polarization curves, despite some changes in chemical composition of coatings, do not essentially differ. With this, the potential of corrosion shifts towards the segment of negative values, and the corrosion current of such coatings are within one decimal order of their values. Open porosity, that is an important factor, which influences the 
corrosion behaviour of the material and its matrix is a characteristic feature of all the coatings. The corrosive medium, because of the presence of porosity, penetrates through such pores down to the matrix and creates conditions for proceeding of under-coating corrosion. In this case, products of corrosion accumulate at the coating - matrix interface, and they cause the separation of the coating from the basis (phenomena of ply-separation).

The presence of chromium, ferro-chromium, ferro-silicon, and ferro-manganese in the charge for $\mathrm{CW}$ 90Cr17BMnSi leads to minimal chemical heterogeneity of the coating, and consequently to high corrosion resistance of the coating. The presence of ferro-chromium-boron, chromium, and self-fluxing alloying composition in the charge for $\mathrm{CW} 20 \mathrm{Cr} 16 \mathrm{~B} 3 \mathrm{Ni} 2 \mathrm{SiAl}$ ensures high content of chromium in the coating, low coefficient of microheterogeneity, and high resistance against corrosion.

Keywords: arc-sprayed coatings, cored powders, corrosion, metallization, residual stresses, electrochemical parameters, porosity.

\section{Introduction and problem statement}

The arc-sprayed metallization (ASM) is the cheapest and the most widespread method of deposition of gas-thermal wear resistant coatings; this method ensures high rate of the deposition of coatings [1]. The application of CWs as electrode materials enables us to expand the sphere of application of such coatings, to increase their hardness, wear resistance, thermal resistance and resistance against corrosion [2-7]. However, nowadays the relation between the chemical composition of the $\mathrm{CW}$ and mechanical characteristic of coatings and the relation of chemical composition of the $\mathrm{CW}$ and the corrosion resistance under the conditions of long-term operation in a corrosive medium is investigated insufficiently.

\section{Analysis of modern information sources on the theme of the paper}

By means changing and varying components of the charge, it is possible to charge and vary the chemical composition of the $\mathrm{CW}$ in wide ranges; and thus, it is possible to obtain coatings of different operational properties $[2,4]$. In order to obtain coatings with high operational characteristics, world's leading researchers change not only the chemical composition of the charge, but the material of the shell of the $\mathrm{CW}$ as well ( $\mathrm{Al}, \mathrm{Fe}, \mathrm{Ni}$ ) [6-8]; besides, to reduce the porosity of coatings and to reduce the oxygen content in coatings, the chemical composition as well as parameters of the gas-spray.

\section{Aim and task of the investigation}

The aim and the task of the investigation is to study the effect of the charge content of the $\mathrm{CW}$ on the strength of arc-sprayed coatings and on their corrosion resistance in $3 \%$ aqueous solution of $\mathrm{NaCl}$.

\section{Test methods}

For arc-spraying of coatings, there were used CWs [9]. For their shells the strip of the 0,8nc lowcarbon steel was used. As chromium-containing components of the charge, low-cost ferro-alloys were used (Table 1).

The process of supplying a specimen with ASC consist of the following operations: degreasing of its surface, peeing by corundum, arc-spay deposition of a coating and control of quality of the coating, and grinding of the specimen. Parameters of arc-spray deposition of coatings after shot-peening (treatment by corundum) of a specimen: current $-150 \mathrm{~A}$, operating voltage $-32 \mathrm{~V}$, distance from the nozzle to the surface of deposition $-150 \mathrm{~mm}$, pressure of the compressed air - $0.65 \mathrm{MPa}$.

Determination of the first-type residual stresses in the coatings was conducted according [10] to the developed for bimetal rings whose ratio of the radii of their central line to the radial thickness of the ring is not less than 10. In particular, the expression (1) is presented below, there for determination the stresses the module of elasticity of the steel substrate ring and that of the deposited lager are taken into account:

$$
\sigma_{\mathrm{tg}}=\left(2 \cdot E_{1} / D_{t}^{2}\right) \cdot\left[\left(0,5 \cdot\left(t_{2}^{2} \cdot c+t_{1}^{2}+2 \cdot t_{1} \cdot t_{2} \cdot c\right) /\left(t_{2} \cdot c+t_{1}\right)-(a+d a)\right] \cdot \Delta D,\right.
$$

where $\mathrm{D}$ is the diameter of the ring; $t_{1}$ is the thickness of the ring; $t_{2}$ is the thickness of the deposited layer; $t$ is the thickness of the ring together with the deposited ASC; $c=E_{1} / E_{2}\left(E_{1}, E_{2}\right.$ are modules of elasticity of 
steel and of the deposited ACC, respectively); $d$ is the distance from the surface of deposition of the coating to the investigated elementary layer; $d \mathrm{a}$ is the thickness of the investigated elementary layer.

Table 1

Powder components for CWs making

\begin{tabular}{|c|c|c|c|c|c|c|c|c|c|c|c|}
\hline \multirow{2}{*}{ Alloy } & \multicolumn{11}{|c|}{ Content of the elements, $\%$ mass. } \\
\hline & $\mathrm{Cr}$ & $\mathrm{Fe}$ & $\mathrm{Mn}$ & $\mathrm{Ni}$ & $\mathrm{Al}$ & $\mathrm{Cu}$ & $\mathrm{B}$ & $\mathrm{Si}$ & $\mathrm{C}$ & $\mathrm{S}$ & $\mathrm{P}$ \\
\hline $\begin{array}{l}\text { High-carbon ferrochromium } \\
\text { (ГОСТ 4757-85) }\end{array}$ & 65.0 & - & - & - & - & - & - & 2.0 & 8.0 & 0.08 & 0.05 \\
\hline $\begin{array}{l}\text { Ferro-manganese } \\
(\text { (ГОСТ 4755-80) }\end{array}$ & - & - & 85.0 & - & - & - & - & 2.0 & 0.5 & 0.03 & 0.30 \\
\hline $\begin{array}{l}\text { Chromium metal } \\
\text { (ГОСТ 5905-2004) }\end{array}$ & 99 & $\leq 0.5$ & - & - & $\leq 0.5$ & $\leq 0.02$ & - & $\leq 0.2$ & $\leq 0.03$ & $\leq 0.02$ & $\leq 0.02$ \\
\hline $\begin{array}{c}\text { Iron chrome boron ligature } \\
\text { (ТУ 14-5-106-73) }\end{array}$ & 42.4 & 30.1 & - & - & 2.0 & - & 22.0 & 2.8 & - & - & - \\
\hline $\begin{array}{c}\text { Ferro-silicon } \\
(\text { ГОСТ 1415-93) }\end{array}$ & 0.4 & - & 0.4 & - & 2.0 & - & - & $63-68$ & - & 0.02 & 0.05 \\
\hline $\begin{array}{l}\text { ПГ10-H-01 Ni self-flux } \\
\text { (ТУ 48-19-383-84) }\end{array}$ & 20.0 & 7.0 & - & base & - & - & 4.2 & 4.5 & 1.0 & - & - \\
\hline
\end{tabular}

The tensile strength (cohesion) of the ASC was determined in the specimen 1, which consists of the pipes tightened together by the pin 2 , having used the protective washers 3 ; the spring 4 ; and the nut 5 (Fig. 1). On the lateral surface of an assembled in this way specimen, ASC was deposited along perimeter of the butt-joint of the mandrel was removed from the specimen, and the latter was being extended with recording the load at the instant of fracture of the coating at the place of the butt-joint of the two parts of the pipe.

The experimental investigations were conducted in an electrochemical cell potentiodynamic mode with the use of soft-ware-hardware complex which is designed for automation of electrochemical investigations with the help of CBA-1B-M volt-amperometric system. The reference electrode was of silver chloride (EBL-1M1-type). The rate of change of potential amounted to $2 \mathrm{mV} / \mathrm{s}$.

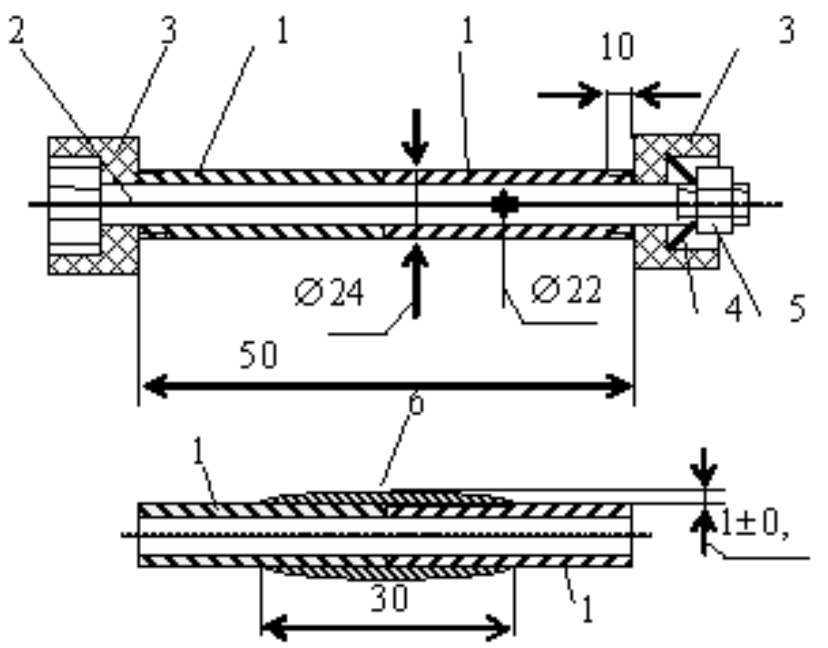

Fig. 1. Schematic diagram of device for deposition of coating onto specimen for determining tensile cohesion of ASC

The rate of corrosion was determined by means of extrapolation of linear segments of polarization curves to the corrosion potential. For electrochemical investigations, the working part of surface of the specimen was isolated by cylindrical cells whose area was $3.14 \mathrm{~cm}^{2}$. 


\section{Results of experiments}

In the course of development of CWs for arc-sprayed deposition of coatings for operation of latter's under the conditions of abrasive wearing in corrosive media, it is necessary to use CWs of as small as possible diameter. However, it is not always possible, because it is necessary to ensure the necessary amount of chromium-containing, carbon-containing and boron-containing components of the charge for CWs obtaining. To archive the amount of chromium over $15 \%$ in mass in a coating, it is necessary to use CWs whose diameters are of $1.8-2.2 \mathrm{~mm}$.

For arc-spray deposition of corrosion-resistant coating, experimental batches of charge materials in the form of CWs (Table 2) which promote formation of low-temperature melt able eutectics in charge materials, homogenize $\mathrm{CW}$ melts, and reduce microhomogenity of coatings.

Table 2

Mechanical characteristics of coatings obtained from CWs

\begin{tabular}{|c|l|c|c|c|c|c|}
\hline Coating & Material of wire & $\begin{array}{c}\varnothing, \\
\mathrm{mm}\end{array}$ & $\begin{array}{c}\text { Filling } \\
\text { factor }\end{array}$ & $\begin{array}{c}\text { First-type stresses in } \\
\text { coating, MPa }\end{array}$ & $\begin{array}{c}\text { Cohesive } \\
\text { strength, MPa }\end{array}$ & $\begin{array}{c}\text { Microhardness, } \\
\text { HV }\end{array}$ \\
\hline 1 & $60 \mathrm{Cr} 15 \mathrm{~B} 2 \mathrm{MgSi}$ & 2.2 & 22.8 & 23.6 & 140 & 560 \\
\hline 2 & Si16 & 2.0 & 25 & 38.0 & 50 & 460 \\
\hline 3 & Cr17B3SiAl & 2.2 & 27 & 61.7 & 80 & 700 \\
\hline 4 & $90 \mathrm{Cr} 17 \mathrm{BMnSi}$ & 2.0 & 27 & 76.9 & 185 & 625 \\
\hline 5 & $75 \mathrm{Cr} 19 \mathrm{~B} 3 \mathrm{Si} 2$ & 2.2 & 25 & 66.8 & 150 & 545 \\
\hline 6 & 11Cr14B3Si2Al & 1.8 & 24 & 43.75 & 100 & 650 \\
\hline 7 & 20Cr16B3Ni2SiAl & 1.8 & 27 & 41.9 & 100 & 690 \\
\hline
\end{tabular}

Mechanical characteristics of coatings deposited from CWs. The greatest hardness is possessed by coatings made of $\mathrm{CW} 20 \mathrm{Cr} 16 \mathrm{~B} 3 \mathrm{Ni} 2 \mathrm{SiAl}, \mathrm{CW} \mathrm{Cr} 17 \mathrm{~B} 3 \mathrm{SiAl}$ and $\mathrm{CW} 11 \mathrm{Cr} 14 \mathrm{~B} 3 \mathrm{Si} 2 \mathrm{Al}$ materials. It is due to $3 \%$ of boron in the charge materials of these CWs that ensure high hardness of these coatings. Borum is introduced into the charge of these CWs in the form of FHB-2 ferrochlorine-bromium. In the ferrite structure of such coatings (according to data of phase analysis), there are fine-disperse inclusions of $\mathrm{FeCrB}$ and $\mathrm{FeCr} 2 \mathrm{~B}$ borides. However, the cohesive strength of such coatings does not exceeded $100 \mathrm{MPa}$. This is caused by the fact that in the course of coatings deposition there emerge first-type tensile stresses in their structures; because during crystallization and cooling of droplets (lamels) on the surface of substrate the coating decreases in its size. This causes emergence of first-type tangential stresses. Such stresses can cause the emergence of cracks during the machining which follows. For responsible machine parts, it is necessary to ensure their heating up to $150-200{ }^{\circ} \mathrm{C}$ prior to deposition of coatings from these wires onto their surfaces.

Admixing of boron carbide, as a boron-containing component, does not ensure sufficiently high hardness of these coatings. It is obvious that in this case boron carbide does not completely dissolve in the CW melt, from which the coating forms. A considerable fraction of boron carbide is blown out of the charge material during deposition of coatings.

Somewhat less hardness is possessed by coatings made of $\mathrm{CW} 90 \mathrm{Cr} 17 \mathrm{BMnSi}$ material. Such hardness is ensured by the martensite matrix of the coating, the matrix is strengthened by fine-dispersion inclusions of $\mathrm{FeCr} 2 \mathrm{~B}$ borides. The coatings made from such $\mathrm{CWs}$ are of essentially higher cohesive strength stresses. Since the coefficient of thermal exposition of martensite is the least one, and that of austenite is the greatest one, it is emergence of only inconsiderable tensile stresses that takes place in the coating during formation of matrix phase of martensite. Such coatings are easily machining more rigid regimes can be applied.

Corrosion resistance of coatings made from the interested CWs. Because of peculiarities of the process of arc-spray deposition from CWs, there form coatings of high chemical heterogeneity (Table 3). Since under high electrochemical microheterogeneity of surface the development of localized corrosion processes is possible, and these processes promote corrosion-mechanical destruction of steel; in order to archive improved resistance against corrosion it is necessarily to ensure low chemical heterogeneity. To 
quantify this chemical microheterogeneity $(\mathrm{CMH})$, a new parameter, namely the microheterogeneity coefficient $K_{C M H}$, is introduced:

$$
K_{C M H}=\left(\sum_{i=1}^{n}\left|c_{e v r}-c_{i}\right|\right) / n \times c_{e v r},
$$

where $K_{C M H}$ characterizes the deviation of component's content measured in individual lamella $c_{i}$ from its average content in the coating $c_{e v r}$ by the number of measures $n$.

This can be achieved by means of introduction of components which form easily melt able eutectics between themselves and between the $\mathrm{CW}(\Pi \Gamma-10 \mathrm{H}-01, \mathrm{Fe}-\mathrm{Mn}, \mathrm{Fe}-\mathrm{Si})$ shell into the charge for CWs.

Table 3

Microheterogeneity of coatings made from investigated CWs

\begin{tabular}{|c|c|c|c|c|c|c|c|c|}
\hline \multicolumn{9}{|c|}{ CW 60Cr15B2MnSi } \\
\hline Content of $\mathrm{Cr}$ in a lamele of coating, mass. \% & 17 & 14 & 13.5 & 13.9 & 13.7 & 14 & 13.7 & 13.7 \\
\hline Content of Si in a lamele of coating, mass. \% & 3.5 & 4.4 & 4.1 & 4.4 & 4.2 & 4.3 & 4.3 & 4.5 \\
\hline $\begin{array}{l}\text { Deviation of chromium concentration from its mean value } \\
\text { over all the lameles }\end{array}$ & 2.8 & -0.2 & -0.7 & -0.3 & 0.5 & -0.2 & -0.5 & -0.5 \\
\hline
\end{tabular}

\begin{tabular}{|l|c|c|c|c|c|c|c|c|}
\hline CW 90Cr17BMnSi & 17.6 & 16.3 & 19.2 & 18.8 & 17 & 16.3 & 17 & 17.1 \\
\hline Content of Cr in a lamele of coating, mass. \% & 1.2 & 1.2 & 1.6 & 1.4 & 1.1 & 0.9 & 1.4 & 1.2 \\
\hline Content of Si in a lamele of coating, mass. \% & 0.2 & -0.9 & 1.8 & 1.4 & -0.4 & 1.1 & 0.4 & 0.3 \\
\hline $\begin{array}{l}\text { Deviation of chromium concentration from its mean value } \\
\text { over all the lameles }\end{array}$ & $K_{C M H}=0.05$ \\
\hline \multicolumn{7}{|c|}{$\mathrm{Cr}_{\text {evr }}=17.4$} \\
\hline
\end{tabular}

\begin{tabular}{|l|c|c|c|c|c|c|c|c|c|}
\hline \multicolumn{1}{|c|}{ CW Cr17B3SiAl } \\
\hline Content of Cr in a lamele of coating, mass. \% & 15.2 & 21.1 & 14 & 18.4 & 19.6 & 19.3 & 15 & 14.6 \\
\hline Content of Si in a lamele of coating, mass. \% & 1.7 & 1.8 & 1.0 & 1.2 & 1.6 & 2.1 & 2 & 1.6 \\
\hline $\begin{array}{l}\text { Deviation of chromium concentration from its mean } \\
\text { value over all the lameles }\end{array}$ & -0.19 & 4.0 & -2.1 & 1.3 & 2.5 & 2.2 & -2.1 & -2.5 \\
\hline & $\mathrm{Cr}_{\text {evr }}=17.1$ & $K_{C M H}=0.15$ \\
\hline
\end{tabular}

\begin{tabular}{|c|c|c|c|c|c|c|c|}
\hline \multicolumn{8}{|l|}{ CW 75Cr19B3Si2 } \\
\hline Content of $\mathrm{Cr}$ in a lamele of coating, mass. \% & 23 & 15.5 & 15.6 & 18.5 & 18.3 & 19.1 & 20 \\
\hline Content of Si in a lamele of coating, mass. \% & 1.4 & 1.2 & 1.4 & 1.5 & 1.3 & 1.9 & 2 \\
\hline $\begin{array}{l}\text { Deviation of chromium concentration from its mean value over all } \\
\text { the lameles }\end{array}$ & 4.4 & -3.1 & -3.0 & -0.1 & -0.3 & 0.6 & 1.4 \\
\hline
\end{tabular}

\begin{tabular}{|l|c|c|c|c|c|c|c|c|c|}
\hline \multicolumn{10}{|c|}{ CW 11Cr14B3Si2Al } \\
\hline Content of Cr in a lamele of coating, mass. \% & 18.3 & 11.3 & 21.6 & 14.3 & 10.3 & 15.4 & 10.6 & 10.7 & 11.5 \\
\hline Content of Si in a lamele of coating, mass. \% & 2.6 & 1.8 & 3.8 & 2.4 & 1.5 & 2.4 & 1.9 & 2.2 & 2.4 \\
\hline $\begin{array}{l}\text { Deviation of chromium concentration from its } \\
\text { mean value over all the lameles }\end{array}$ & 4.2 & -2.8 & 7.5 & 0.2 & -4.1 & 1.3 & -4.1 & -3.4 & -2.6 \\
\hline \multicolumn{7}{|c|}{$K_{C M H}=0.24$} \\
\hline
\end{tabular}

\section{CW 20Cr16B3Ni2SiAl}

\begin{tabular}{|l|c|c|c|c|c|c|c|c|}
\hline Content of $\mathrm{Cr}$ in a lamele of coating, mass. \% & 17.2 & 15.5 & 18.1 & 13.3 & 16.3 & 17.2 & 17.1 & 16.3 \\
\hline Content of $\mathrm{Si}$ in a lamele of coating, mass. \% & 0.7 & 0.5 & 0.5 & 0.6 & 0.5 & 0.6 & 0.6 & 0.5 \\
\hline Content of $\mathrm{Ni}$ in a lamele of coating, mass. \% & 2.0 & 2.2 & 1.8 & 2.2 & 2.2 & 2.3 & 1.4 & 2.3 \\
\hline $\begin{array}{l}\text { Deviation of chromium concentration from its mean } \\
\text { value over all the lameles }\end{array}$ & 0.8 & -0.9 & 1.7 & -3.1 & -0.1 & 0.8 & 0.7 & -0.1 \\
\hline \multicolumn{4}{|c|}{$K_{C M H}=0.06$} \\
\hline
\end{tabular}


The least coefficient of microheterogeneity is a feature of $\mathrm{CWs} 90 \mathrm{CrBMnSi}\left(\mathrm{K}_{\mathrm{CMH}}=0.05\right)$ and $\mathrm{CWs}$ $20 \mathrm{Cr} 16 \mathrm{~B} 3 \mathrm{Ni} 2 \mathrm{SiAl}\left(\mathrm{K}_{\mathrm{CMH}}=0.06\right)$.

From potentiodynamic investigations, the behaviour of ASCs obtained from CWs of different composition of their charge materials has been recognized in $3 \% \mathrm{NaCl}$ solution (Figs. 2-3).

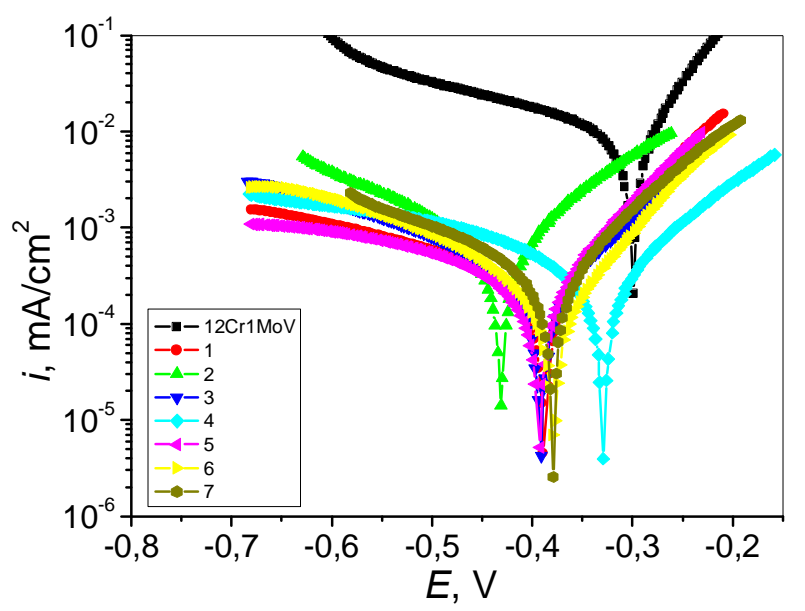

$a$

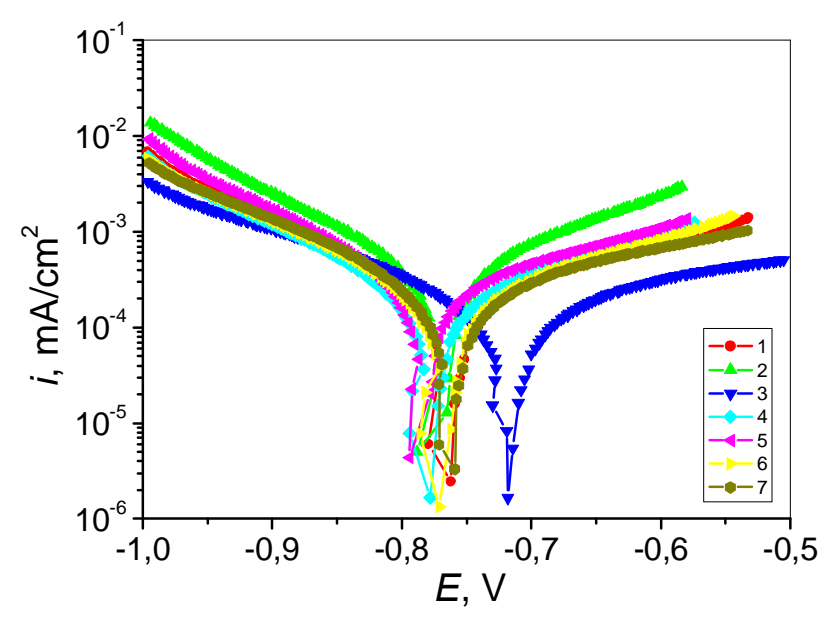

$c$

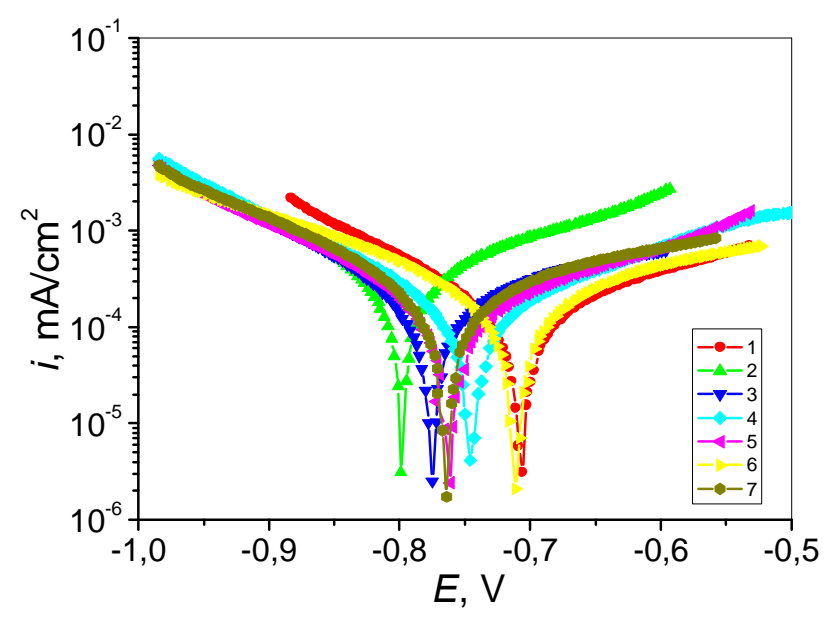

$b$

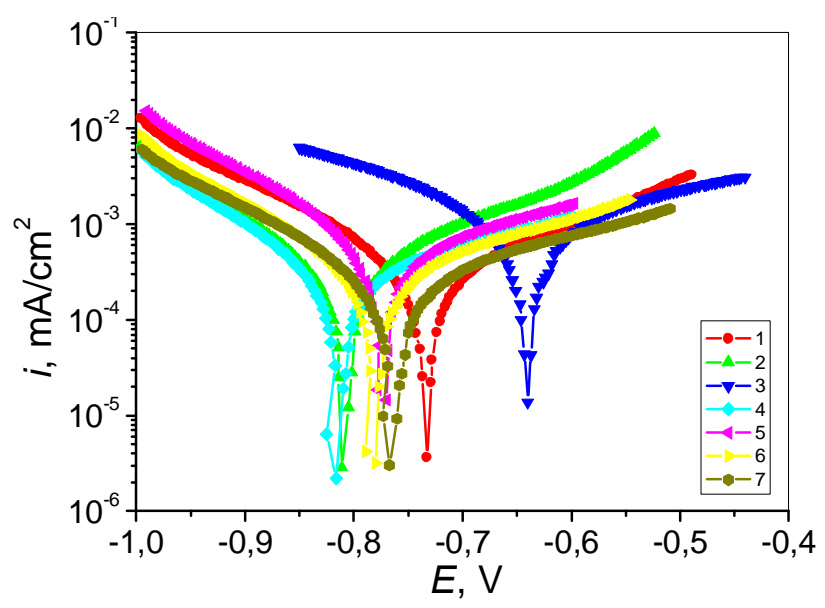

$d$

Fig. 2. Potentiodynamic curves of ASCs deposited from wires of different composition (table 4) in different duration of exposing them in $3 \% \mathrm{NaCl}$ solution medium: $a-1$ hour, $b-1$ day, $c-3$ days, $d-7$ days

The electrochemical parameters and the character of the polarization curves, despite some charges in chemical composition of coatings, do not differ greatly. The corrosion potential shifts towards negative values with time, but currents of corrosion of such coatings charge within one decimal order.

Open porosity is characteristic of all ASCs; such porosity is an important factor which influences the corrosion properties both of the coating and the substrate. The corrosive medium penetrates through pores up to the substrate and causes corrosion between the coating and the substrate. In this case, the products of corrosion increase in volume, and thus, initiate ply separating, i.e. the coating is separated from the substrate.

It is found that with the increase in the duration of the exposing to 7 days the corrosion potential of coated steel shifts towards to negative values by $0.3-0.4 \mathrm{~V}$. Such a shifts of potential by $0.3-0.4 \mathrm{~V}$ is caused by the presence such alloying elements as $\mathrm{Al}$, and $\mathrm{Mn}$ in lameles of the coating. These chemical elements are anode inclusions relatively to the steel substrate, which serves a cathode there. 
It is also found that in the first stage the electrochemical corrosion is controlled by cathode process $(b c>b a)$. The cathode restoration of the oxidant is the limiting stage of the process (Fig. 2, a). And on the contrary, the electrochemical corrosion proceeds with anode control $(b a>b c)$ after the increase in duration of exposing the coatings in $3 \% \mathrm{NaCl}$ solution; the limiting stage of the corrosion process is the reaction of anodic oxidation of metal (Fig. 2, $b-d$ ).

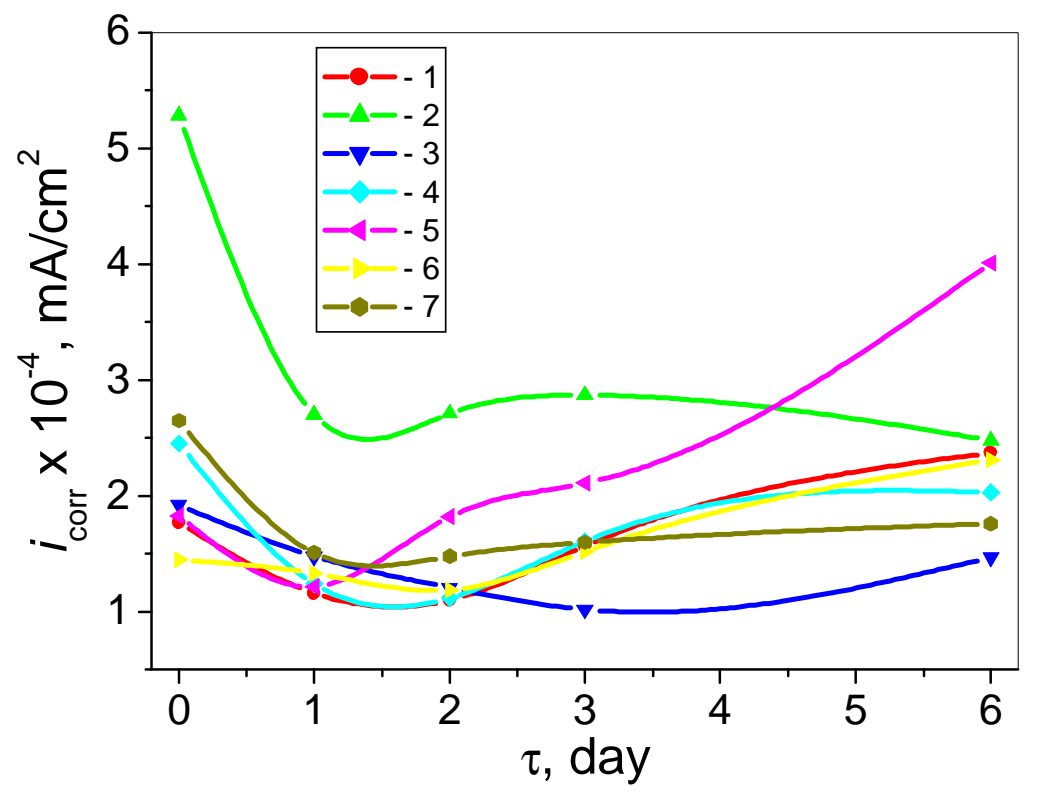

Fig. 3. Corrosion currents of coatings depending on duration of coatings in $3 \% \mathrm{NaCl}$ solution

With the increase in the duration up to 2 days of exposition, the currents of corrosion decrease; for the wires (4) and (5), the currents increase, and for the rest of them the corrosion current stabilizes at rather considerable low level. The cause of high corrosion currents for the wires (5) and (6) is their high porosity, which causes penetration of corrosive medium up to the substrate, this causes corrosion between the coating and the substrate (Fig. 4, Fig. 5). For the wire (6), the high values of corrosion current is caused by formation of chromium-containing borides, due to which in the solid solution the amount by chromium decreases below the critical level (11\%).

To prevent penetration of corrosive working medium through pores inside the coating (down to the very substrate, there was suggested previous soaking the coating with I-20 mineral oil, with Castrol magnetic 10W40 synthetic motor oil or with $3 \%$ aqueous solution of Hydroway 1060 emulsol; these substances are used as working fluids in hydrocylinders of different purposes.

The initial electrode potential of coating in the "acid rain" medium amount to $-250 \mu \mathrm{V}$. In the course of exposition of the specimen up to 75 hours (Fig. 6), its corrosion potential decreases from -250 to $-450 \mu \mathrm{V}$, and its value reaches that of the steel substrate; and this means that the corrosive medium has penetrated down the very substrate.

The soaking with I-20 motor oil leads to insufficient shift of potential towards positive value, i.e. to $-400 \mu \mathrm{V}$; and this means that the medium penetrates down to the very substrate also in this case.

The soaking of the coating with 10W40 oil or with "Hydroway 1060" emulsol effectively shifts electrode potential towards its positive values. This causes the decrease in corrosion currents by three decimal orders. It is obvious that this oil and emulsol do not prevent penetration of the corrosive medium inside the coating and to the steel substrate alone, but also effectively inhibited the coating and the substrate. 


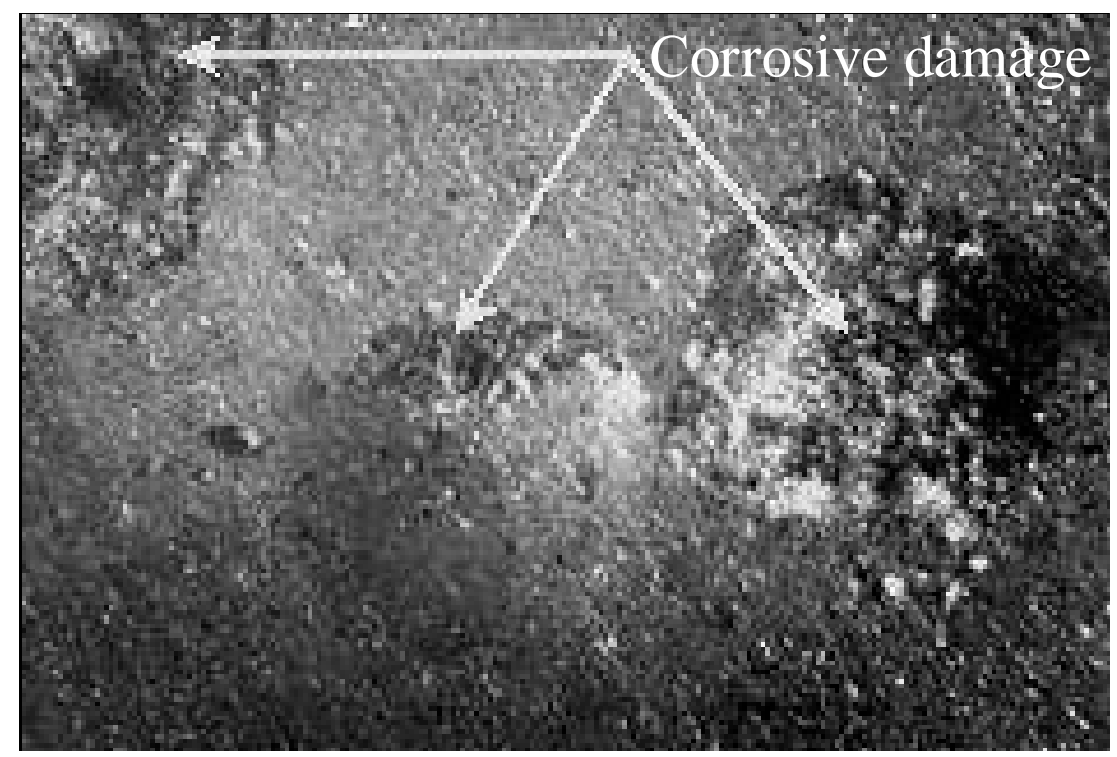

Fig. 4. Corrosion at substrate ASC interface

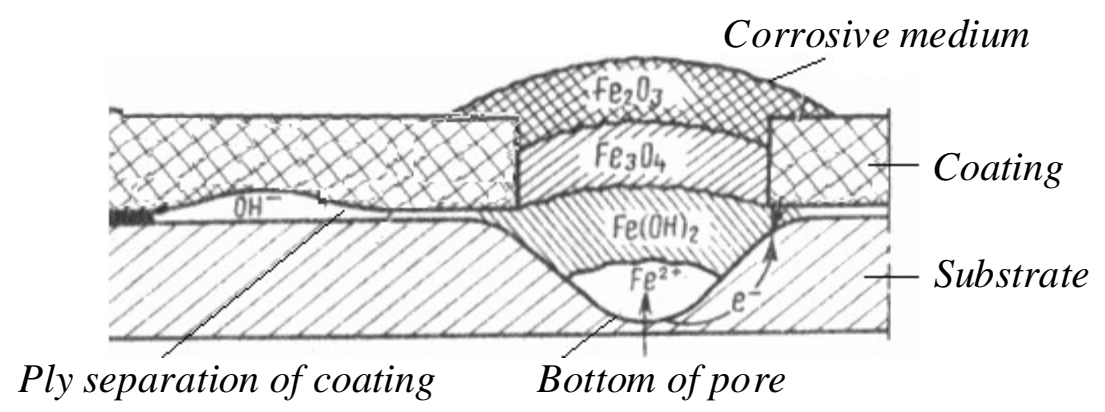

Fig. 5. Scheme of processes that occur in a pore

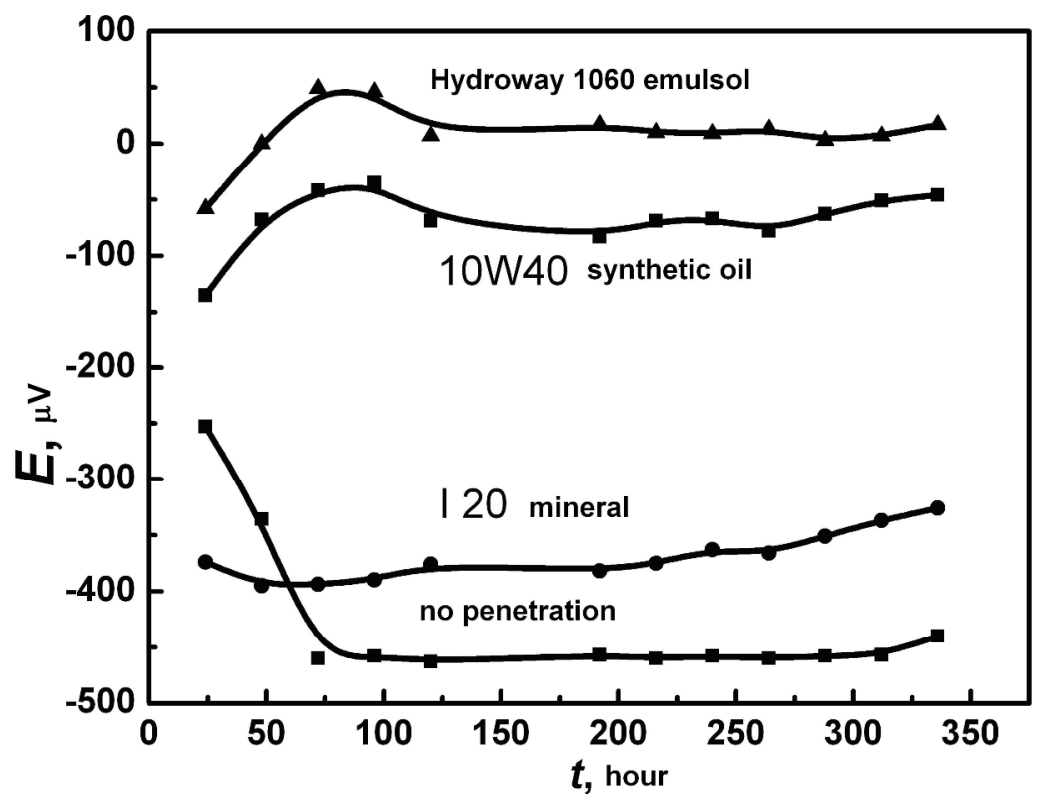

Fig. 6. Variation of electrode potential E of coating from $\mathrm{CW}$ Cr17B3SiAl depending on duration of exposition in "acid rain" medium in different soaking fluids 
Conclusions

1. To deposit corrosion resistant arc-sprayed coatings, it is necessary that the charge materials and the shells of cored wires form low-temperature meltable eutectics between them.

2. To ensure both high wear resistance and high corrosion resistance, it is necessary that the coating contain more than $14 \%$ of $\mathrm{Cr}$. Therefore, the charge materials must contain pure chromium, high-carbon ferrochromium, ferrochromium-boron, ferrosilicon and ferromanganese.

3. The previous soaking of coatings with 10W40 motor oil or with $3 \%$ "Hydroway 1060 " prevents penetration of the corrosive medium into the pores of the coatings; and such a soaking reduces the density of corrosion currents from $10^{-3}$ to $10^{-6} \mu \mathrm{A} / \mathrm{cm}^{2}$ in neutral water medium; in slightly acidic equate environment from $10^{-3}$ to $10^{-4}$.

\section{References}

[1] V. M. Korzh, et al., Nanesennia pokryttia [Coating]. Kyiv, Ukraine: Aristei Publ., 2005. [In Ukrainian].

[2] V. Pokhmurskyi, et al., "Arc-sprayed iron-based coatings for erosion-corrosion protection of boiler tubes at elevated temperatures", Journal of Thermal Spray Technology, Issue 5, no. 22, pp. 808-819, 2013.

[3] B. Wielage, et al., "Iron-based coatings arc-sprayed with cored wires for applications at elevated temperatures", Surface and coating technology, no. 220, pp. 27-35, 2013.

[4] V. Pokhmurskyi, et al., "Electrochemical properties of arc sprayed coatings from cored wires on the basis of cheap ferroalloys", Ochrona przed korozja, no. 11, pp. 516-518, 2013.

[5] V. Pokhmurskyi, et al., "Gazoabrazivnaia iznosostoikost pri povyshennykh temperaturakh pokrytii, poluchennykh dugovoi metallizatsiei" ["Gasoabrasive wear resistance at elevated temperatures of coatings produced by thermal spraying"], Avtomaticheskaia svarka [Automatic Welding], no. 6, pp. 16-23, 2013. [in Russian].

[6] V. Pokhmurskyi, et al., "Struktura, mekhanichni ta elektrokhimichni kharakterystyky koroziinostiikykh elektroduhovykh pokryttiv iz poroshkovykh drotiv" ["Structure, mechanical and electrochemical characteristics of corrosion-resistant electric arc coatings from powdered wires"], Naukovi notatky [Scientific Notes], vol. 41, part 2, pp. 127-132, 2013. [in Ukrainian].

[7] V. Pokhmurskyi, et al., "Zasady stvorennia koroziinostiikykh elektroduhovykh pokryttiv iz poroshkovykh drotiv" ["Principles of creation of corrosion-resistant electric arc coatings from powdered wires"], Fizyko-khimichna mekhanika materialiv [Physico-Chemical Mechanics of Materials], special issue 9, vol. 2, pp. 600-606, 2012. [in Ukrainian].

[8] K. A. Yushchenko, et al., Inzheneriia poverkhni [Surface engineering]. Kyiv, Ukraine: Naukova Dumka Publ., 2007. [In Ukrainian].

[9] H. V. Pokhmurska, M. M. Student, and V. I. Pokhmurskyi, Hazotermichni pokryttia [Gas-thermal coatings]. Lviv, Ukraine: Prostir-M Publ., 2017. [In Ukrainian].

[10] M. A. Babichev, Metody opredeleniia vnutrennikh napriazhenii v detaliakh mashin [Methods for determining internal stresses in machine parts]. Moscow, Russia: AN SSSR Publ., 1955. [in Russian]. 